\title{
Dynamical Analysis of a Cable Manipulator Using Multibody Approaches
}

Radek Bulín ${ }^{1}$, Michal Hajžman ${ }^{1}$, Pavel Polach², Zbyněk Šika ${ }^{3}$, Jan Zavřel ${ }^{3}$

${ }^{1}$ Department of Mechanics, Faculty of Applied Sciences, University of West Bohemia, Univerzitní 22, 30614 Plzen̆, Czech Republic. E-mail: rbulin@kme.zcu.cz, mhajzman@kme.zcu.cz

${ }^{2}$ NTIS - New Technologies for the Information Society, Faculty of Applied Sciences, University of West Bohemia Univerzitní 22, 30614 Plzeň, Czech Republic. E-mail: ppolach@ntis.zcu.cz

${ }^{3}$ Department of Mechanics, Biomechanics and Mechatronics, Faculty of Mechanical Engineering, Czech Technical University in Prague, Technická 4, 16607 Praha. E-mail: zbynek.sika@fs.cvut.cz, jan.zavrel@fs.cvut.cz

This paper deals with the creation of a computational model of a particular cable manipulator composed of a rigid manipulator with three degrees of freedom and a platform driven by four fibers. Each fiber is led over a pulley and is driven by a linear motor, which can be controlled. The multibody dynamics approach is a suitable way in order to create the manipulator model. The most common cable modelling techniques are summarized in this paper and then the computational model of the cable manipulator QuadroSphere is created using MSC.Adams software. The computational model verification is done using the modal analysis of linearized model and the experimental modal analysis on the real set up. Further results of various numerical simulations are presented and their utilization is discussed.

Keywords: Cable Manipulator, Multibody Dynamics, Cable Modelling, QuadroSphere

\section{Acknowledgement}

The paper has originated in the framework of solving the project of the Czech Science Foundation No. 15-20134S entitled "Multi-level Light Mechanisms with Active Structures" and the project SGS-2016-038.

\section{References}

[1] BERZERI, M., SHABANA, A.A. (2000). Development of simple models for the elastic force in the absolute nodal co-ordinate formulation. In: Journal of Sound and Vibration, Vol. 235, No. 4, pp. 539 - 565. Academic Press Ltd, London.

[2] BLATNICKÝ, M., DIŽO, J., TIMOŠČUK, M. (2016). Design of a three-finger robot manipulator. In: Manufacturing Technology, Vol. 16, No. 3, pp. 485 - 489. Institute of Technology and Production Management University of J.E. Purkyne, Ústí nad Labem.

[3] BULÍN, R., HAJŽMAN, M. (2014). On the Modelling of Contact Forces in the Framework of Rigid Body Dynamics. In: Manufacturing Technology, Vol. 14, No. 2, pp. 136 - 141. Institute of Technology and Production Management University of J.E. Purkyne, Ústí nad Labem.

[4] HAJŽMAN, M., BULÍN, R., POLACH, P. (2015). Nonlinear analysis of the cable-pulley interaction. In: Proceedings of the ECCOMAS Thematic Conference on Multibody Dynamics 2015 (J. M. Font-Llagunes, (Ed.)), pp. 554 - 564. International Center for Numerical Methods in Engineering (CIMNE), Barcelona.

[5] HAJŽMAN, M., BULÍN, R., ŠIKA, Z., SVATOŠ, P. (2016). Usage of the particle swarm optimization in problems of mechanics. In: Applied and Computational Mechanics, Vol. 10, No. 1, pp. 15 - 26. University of West Bohemia, Pilsen.

[6] JALÓN, J.G., BAYO, E. (1993). Kinematic and Dynamic Simulation of Multibody Systems - the Real-Time Challenge. Springer-Verlag, New York.

[7] JÓZWIK, J., KURIC, I., OSTROWSKI, D., DZIEDZIC, K. (2016). Industrial Robot Accuracy Testing with QC20W Ballbar Diagnostic System. In: Manufacturing Technology, Vol. 16, No. 3, pp. 519 - 524. Institute of Technology and Production Management University of J.E. Purkyne, Ústí nad Labem.

[8] KAMMAN, J., HUSTON, R. (2001). Multibody dynamics modeling of variable length cable systems. In: Multibody System Dynamics, Vol. 5, pp. 211 - 221. Kluwer Academic Publishers, Netherlands.

[9] NOVAK-MARCINCIN, J., JANAK, M., TAKAC, D. (2014). Computer Design of Robot ABB IRB 140 Transport System from Manufacturing Point of View. In: Manufacturing Technology, Vol. 14, No. 1, pp. 79 - 84. Institute of Technology and Production Management University of J.E. Purkyne, Ústí nad Labem.

[10] PLECHÁČEK, J. (2015). Modelování a řízení poddajných mechanismů robotů. Master thesis, Czech Technical University in Prague, Prague. 
[11] POLACH, P. (2013). Utilization of Multibody Simulations at the Trolleybus Development. In: Manufacturing Technology, Vol. 13, No. 4, pp. 515 - 520. Institute of Technology and Production Management University of J.E. Purkyne, Ústí nad Labem.

[12] POLACH, P., HAJŽMAN, M., ŠIKA, Z., ČERVENÁ, O., SVATOŠ, P. (2014). Influence of the mass of the weight on the dynamic response of the asymmetric laboratory fiber-driven mechanical system. In: Applied and Computational Mechanics, Vol. 8, No. 1, pp. 75 - 90. University of West Bohemia, Pilsen.

[13] POLACH, P., HAJŽMAN, M., VÁCLAVÍK, J., ŠIKA, Z., VALÁŠEK, M.. (2015). Investigation of a laboratory mechanical system with fiber and pulley. In: International Journal of Dynamics and Control, Vol. 3, No. 1, pp. 78 - 86. Springer-Verlag, Berlin.

[14] SHABANA, A.A. (2005). Dynamics of Multibody Systems. Third Edition. Cambridge University Press, Cambridge.

[15] SHABANA, A.A., YAKOUB, R.Y., (2001): Three Dimensional Absolute Nodal Coordinate Formulation for Beam Elements: Theory. In: Journal of Mechanical Design, Vol. 123, pp. 606 - 613. ASME, New York.

\section{Paper number: M201729}

Copyright (C) 2017. Published by Manufacturing Technology. All rights reserved. 